\title{
COMPOSITE-MATERIAL PRINTED ANTENNA FOR A MULTI-STANDARD WIRELESS APPLICATION
}

\author{
TISKANA ANTENA IZ KOMPOZITNEGA MATERIALA ZA \\ VEČSTANDARDNO BREZŽIČNO UPORABO
}

\author{
Touhidul Alam¹, Mohammad Rashed Iqbal Faruque1, Mohammad Tariqul Islam², \\ Norbahiah Misran² \\ 1Space Science Center (ANGKASA), Universiti Kebangsaan Malaysia, 43600UKM Bangi, Selangor, Malaysia \\ ${ }^{2}$ Department of Electrical, Electronic and Systems Engineering, Universiti Kebangsan Malaysia, 43600UKM Bangi, Selangor, Malaysia \\ touhid13@yahoo.com \\ Prejem rokopisa - received: 2014-09-14; sprejem za objavo - accepted for publication: 2014-10-08
}

doi:10.17222/mit.2014.232

This paper presents a printed multi-standard wireless antenna fabricated from a cost effective composite material to cover GPS (1575 MHz), GSM 1800, GSM 1900, WLAN (2400 MHz), LTE band 40 (2.3-2.4 GHz), WiMAX (3600 MHz) and WLAN $(5.1-5.35 \mathrm{GHz})$ frequency bands. The reported antenna is incorporated with two distinct monopole radiators with a meanderline-type ground plane. The wireless mobile antenna can be conveniently simulated with the commercially available EM simulation software (CST Microwave Studio) using the finite-difference time-domain (FDTD) method. A parametric analysis of the antenna geometry is demonstrated and the specific absorption rate (SAR) is also analyzed with a human-head model.

Keywords: antenna, material, multiband, meander line, wireless communication, SAR

Ta članek predstavlja tiskano večstandardno brezžično anteno, izdelano iz cenovno ugodnega kompozitnega materiala, ki obsega frekvenčne pasove GPS (1575 MHz), GSM 1800, GSM 1900, WLAN (2400 MHz), LTE pas 40 (2,3-2,4 GHz), WiMAX (3600 $\mathrm{MHz})$ in WLAN $(5,1-5,35 \mathrm{GHz})$. V predstavljeno anteno sta vgrajena dva različna monopolna sevalnika $\mathrm{V}$ obliki zanke na osnovni ravnini. Brezžično mobilno anteno se lahko prikladno simulira s komercialno razpoložljivo EM simulacijsko programsko opremo (CST Microwave Studio) z uporabo metode domene s končno diferenco časa (FDTD). Prikazana je parametrična analiza geometrije antene in analizirana je bila hitrost specifične absorpcije (SAR) na modelu človeške glave.

Ključne besede: antena, material, večpasovno, linija zanke, brezžična komunikacija, SAR

\section{INTRODUCTION}

Multiband antenna design with a low-profile and stable performance has recently been a significant issue to the researchers. Therefore, research has been focused on minimizing the physical size of individual parts of a modern wireless system. In the most recent years, printed planar antennas have been thought to be most suitable for multiband wireless applications in view of their unique features, for example, light weight, low costs, simple fabrication, multi-frequency mode and stable performances. ${ }^{1,2}$ Several types of multiband antenna have been studied for GPS, GSM, WLAN, LTE band 40, WiMAX and WLAN applications.

A compact dual-arm-structure mobile handset antenna was designed for a multi-band wireless mobile operation, covering DCS, PCS, UMTS and WLAN (2.4 $\mathrm{GHz}$ ) frequency bands. ${ }^{3}$ The dimensions of the antenna were $119 \mathrm{~mm} \times 50 \mathrm{~mm}$. An inverted L-shaped antenna was presented for wireless communication, covering DCS, PCS and IMT tri-bands. ${ }^{4}$ Chen et al..$^{5}$ introduced a modified T-shaped planar monopole antenna for DCS 1800, PCS 1900, UMTS and WLAN applications. However, its dimensions were $65 \mathrm{~mm} \times 40 \mathrm{~mm}$.

This paper presents a multiband printed monopole antenna for wireless communication, which can operate within the existing wireless standards: GPS (1.565-1.585 GHz), GSM (1800, 1900), WiMAX (3.6 GHz), WLAN, LTE band $40(2.3-2.4 \mathrm{GHz})$ and WLAN (5.47-5.9 $\mathrm{GHz}$ ). The overall volume of the proposed antenna is 30 $\mathrm{mm} \times 60 \mathrm{~mm}$, which is at least $26.5 \%$ less $\operatorname{than}^{4}, 50 \%$ less than ${ }^{3}$ and $40 \%$ less than ${ }^{5}$, considering its length and width. However, according to the IEEE and ICNIRP guidelines the specific absorption rate of the proposed antenna must be confirmed and the value should be less than $1.6 \mathrm{~W} / \mathrm{kg}$ in a $1 \mathrm{~g}$ averaging mass and $2 \mathrm{~W} / \mathrm{kg}$ in a $10 \mathrm{~g}$ averaging mass of biological tissues. ${ }^{6,7}$ To comply with this requirement, the SAR value of the proposed antenna was analyzed and compared.

\section{PROPOSED ANTENNA CONFIGURATION}

The geometric configuration and the physical dimensions of the proposed antenna are illustrated in Figure 1. The proposed antenna consists of a meander-line radiator with a defected ground plane. The antenna is printed on an FR4-material (a relative permittivity of 4.6, a loss tangent of 0.02 ) substrate with dimension of $30 \mathrm{~mm} \times 60$ $\mathrm{mm} \times 1.6 \mathrm{~mm}$. A $50 \Omega$ microstrip feeding line is connected with an inverted S-shaped radiator. The specifications of the proposed antenna are listed in Table $\mathbf{1 .}$ 


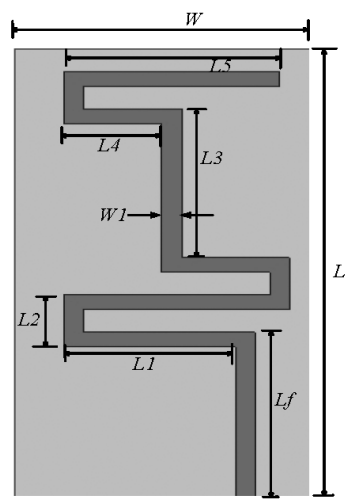

(a)

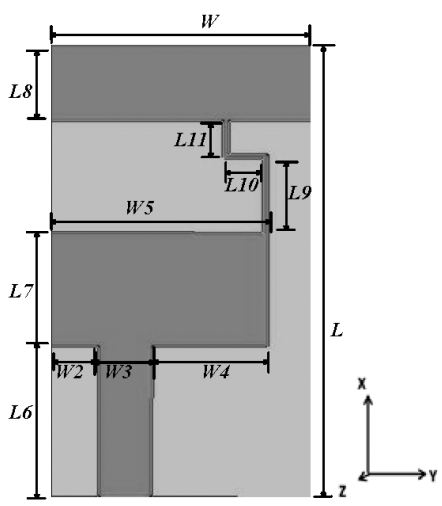

(b)

Figure 1: Geometry of the proposed antenna: a) top view, b) bottom view

Slika 1: Geometrija predlagane antene: a) pogled od zgoraj, b) pogled od spodaj

Table 1: Antenna-design specifications

Tabela 1: Specifikacije antene

\begin{tabular}{|c|c|c|c|}
\hline \multicolumn{5}{|c|}{} \\
\hline Parameter code & Value $(\mathrm{mm})$ & Parameter code & Value $(\mathrm{mm})$ \\
\hline$L$ & 60 & $L 9$ & 10 \\
\hline$W$ & 30 & $L 10$ & 4.5 \\
\hline$L 1$ & 17.5 & $L 11$ & 5 \\
\hline$L 2$ & 7 & $L f$ & 22 \\
\hline$L 3$ & 20 & $W 1$ & 2 \\
\hline$L 4$ & 10 & $W 2$ & 5.87 \\
\hline$L 5$ & 22 & $W 3$ & 6 \\
\hline$L 6$ & 20 & $W 4$ & 13.125 \\
\hline$L 7$ & 15 & $W 5$ & 25 \\
\hline$L 8$ & 10 & & \\
\hline
\end{tabular}

\section{ANTENNA PERFORMANCE WITH AN EPOXY-RESIN-POLYMER SUBSTRATE}

The proposed planar microstrip patch antenna was designed and analyzed using a finite-difference time domain (FDTD) based CST Microwave Studio. The designed antenna was fabricated on a recently available $1.6 \mathrm{~mm}$ thick, low-cost, durable, polymer-resin substrate using an in-house printed-circuit-board (PCB) prototyping machine. The substrate material consists of an epoxy matrix reinforced with woven glass. The composition of epoxy resin and fiber glass varies in the thickness and is direction dependent. One of the attractive properties of polymer-resin composites is that they can be shaped and reshaped repeatedly without losing their material properties. ${ }^{8}$ Due to the lower manufacturing cost, ease of fabrication, design flexibility and market availability of the proposed material, it has become popular for its use as the substrate in patch-antenna designs. The material is composed of $60 \%$ of fiber glass and $40 \%$ of epoxy resin. Figure 2 shows the steps needed to construct an epoxy-resin-polymer substrate (FR4). ${ }^{9}$

Moreover, a parametric study was performed for several substrate materials, illustrated in Figure 3. The

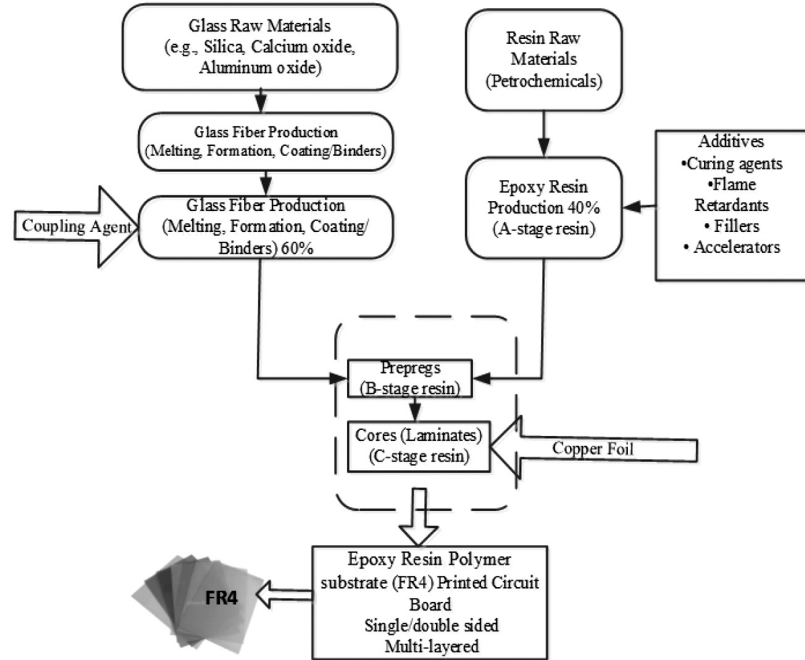

Figure 2: Flow chart of FR4-material construction 9 Slika 2: Shema poteka priprave FR4-materiala ${ }^{9}$

dielectric properties of these materials are listed in Table 2. It is seen from Figure 3 that the FR4 substrate material shows a better performance in terms of reflection coefficient than the other materials listed in Table 2.

Table 2: Dielectric properties of substrate materials

Tabela 2: Dielektrične lastnosti materiala podlage

\begin{tabular}{|c|c|c|}
\hline Substrate material & $\begin{array}{c}\text { Relative permittivity } \\
\left(\varepsilon_{\mathrm{r}}\right)\end{array}$ & $\begin{array}{c}\text { Dielectric loss } \\
\text { tangent }\end{array}$ \\
\hline Glass (Pyrex) & 4.82 & 0.0012 \\
\hline FR4 & 4.60 & 0.02 \\
\hline Taconic CER-10 & 10.00 & 0.0023 \\
\hline Teflon (PTFE) & 2.10 & 0.01 \\
\hline
\end{tabular}

\section{RESULTS AND DISCUSSION}

The prototype of the proposed antenna was fabricated using the FR4 substrate material with a relative permittivity of 4.4 and a loss tangent of 0.02 . The simulated and measured reflection coefficients of the proposed

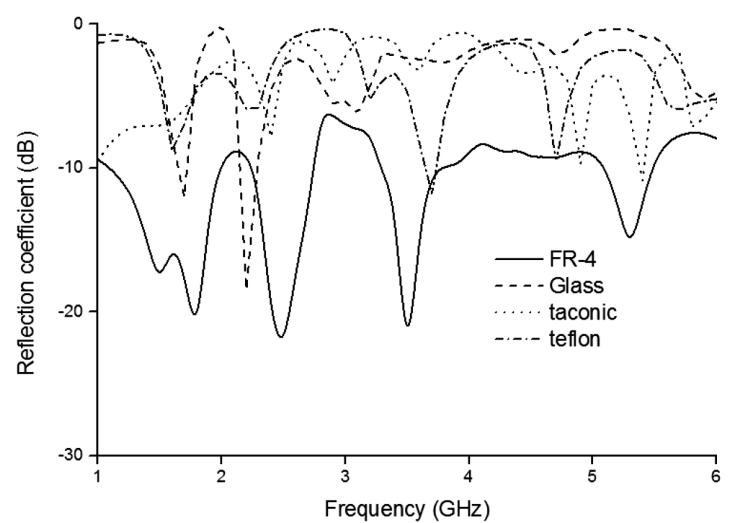

Figure 3: Reflection coefficient of the proposed antenna for the materials listed in Table 2

Slika 3: Koeficient refleksije predlagane antene pri materialih iz tabele 2 


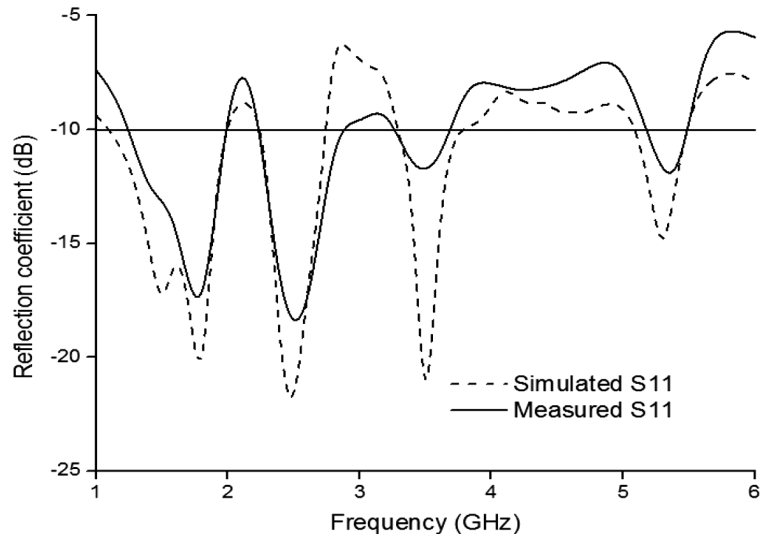

Figure 4: Simulated and measured reflection coefficients of the proposed antenna

Slika 4: Simuliran in izmerjen koeficient refleksije predlagane antene

antenna are presented in Figure 4. The measured and simulated reflection coefficients are identical. It is clearly seen that four operating bandwidths for the multi-band operation are obtained. The measured bandwidths, determined with the reflection coefficient $-10 \mathrm{~dB}$, are 755 $\mathrm{MHz}(1.255-1.98 \mathrm{GHz}), 674 \mathrm{MHz}(2.16-2.89 \mathrm{GHz}), 44$ $\mathrm{MHz}(3.26-3.7 \mathrm{GHz})$ and $34 \mathrm{MHz}(5.14-5.48 \mathrm{GHz})$ which cover GPS (1575 MHz), GSM 1800, GSM 1900, WLAN (2400 MHz), LTE band 40 (2.3-2.4 GHz), WiMAX (3600 MHz) and WLAN (5.1-5.35 GHz).

The surface-current distributions at $1.8 \mathrm{GHz}, 2.4$ $\mathrm{GHz}$ and $3.6 \mathrm{GHz}$ are demonstrated in Figure 5. From

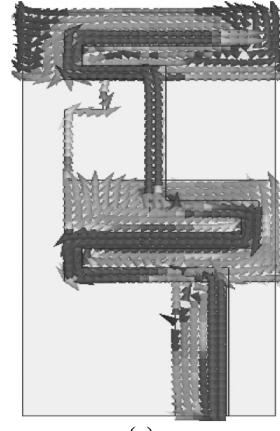

(a)

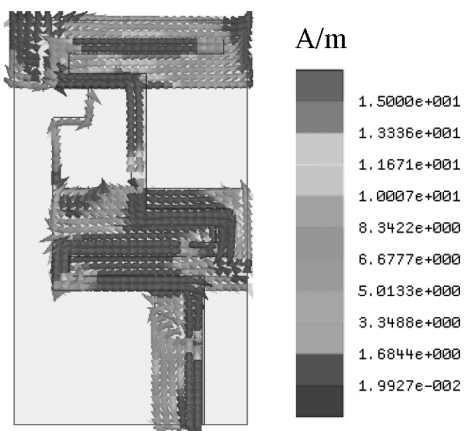

(c)

Figure 5: Surface-current distribution of the proposed antenna: a) 1.8 $\mathrm{GHz}$, b) $2.4 \mathrm{GHz}$ and c) $3.6 \mathrm{GHz}$

Slika 5: Razporeditev tokov na površini predlagane antene: a) 1,8 $\mathrm{GHz}$, b) $2,4 \mathrm{GHz}$ in c) $3,6 \mathrm{GHz}$
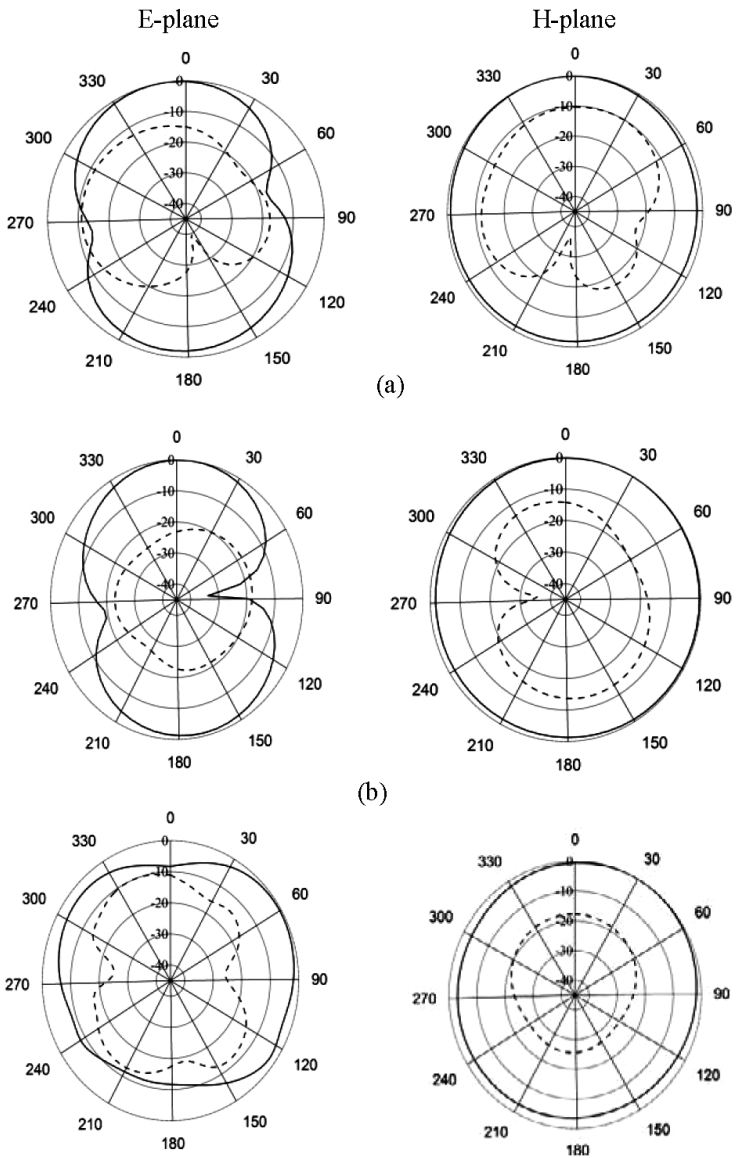

(b)

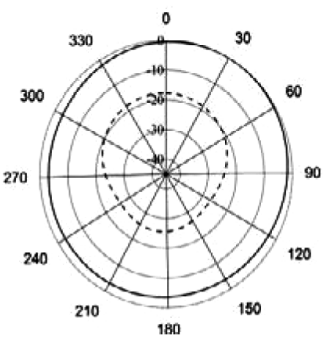

(c)

\section{- Co-polarization}

- - Cross-polarization

Figure 6: Radiation patterns of the proposed antenna for the frequencies of: a) $1.8 \mathrm{GHz}$, b) $2.4 \mathrm{GHz}$, c) $3.6 \mathrm{GHz}$

Slika 6: Vzorec sevanja predlagane antene pri frekvencah: a) $1,8 \mathrm{GHz}$, b) $2,4 \mathrm{GHz}$ in c) $3,6 \mathrm{GHz}$

this figure, it is seen that with the increasing frequency the current flow increased in the $\mathrm{S}$-shaped region. The radiation patterns at $1.8 \mathrm{GHz}, 2.4 \mathrm{GHz}$ and $3.6 \mathrm{GHz}$ are shown in Figure 6. It is clear from this figure that the radiation patterns for both the E-plane and H-plane are omnidirectional at $3.6 \mathrm{GHz}$. But some directivity was

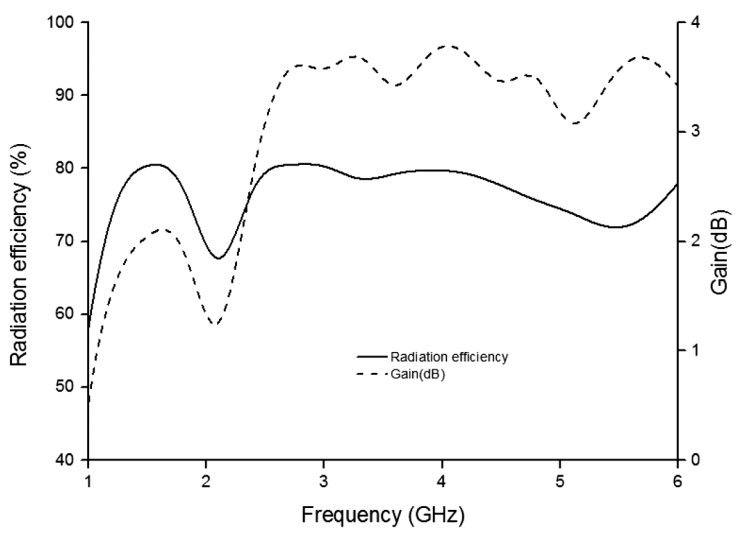

Figure 7: Radiation efficiency and gain of the proposed antenna Slika 7: Učinkovitost sevanja in pridobitev predlagane antene 
shown for the E-plane at $1.8 \mathrm{GHz}$ and $3.6 \mathrm{GHz}$. Moreover, the simulated radiation efficiency and peak gain of the proposed antenna are presented in Figure 7. This figure shows that the maximum radiation efficiency of $81.25 \%$ and the minimum of $67.5 \%$ were achieved. In addition, the maximum peak gain of $3.72 \mathrm{~dB}$ was also obtained with the proposed antenna. A brief comparison of antenna performances is presented in Table 3.

Table 3: Comparison of antenna performances

Tabela 3: Primerjava zmogljivosti antene

\begin{tabular}{|c|c|c|c|c|}
\hline Antenna & $\begin{array}{c}\text { Dimensions } \\
(\mathrm{mm} \times \mathrm{mm})\end{array}$ & $\begin{array}{c}\text { Resonances } \\
(\mathrm{GHz})\end{array}$ & $\begin{array}{c}\text { Bandwidth } \\
(\mathrm{MHz})\end{array}$ & $\begin{array}{c}\text { Max. gain } \\
(\mathrm{dB})\end{array}$ \\
\hline 3 & $119 \times 50$ & $1.71-2.48$ & 770 & $\begin{array}{c}5.4 \mathrm{at} \mathrm{2.15} \\
\mathrm{GHz}\end{array}$ \\
\hline 5 & $65 \times 40$ & $\begin{array}{c}1.66-2.59, \\
4.48-5.89\end{array}$ & 930,1410 & Not given \\
\hline Proposed \\
antenna
\end{tabular}

\section{SPECIFIC ABSORPTION RATE (SAR)}

The analysis of the health risk of the electromagnetic radiation of wireless devices is extensively in progress. These devices paved the way for an extensive utilization of mobile phones in modern society resulting in increased concerns about the inimical radiation..$^{10-12}$ There are several factors that affect the electromagnetic interaction; a close proximity between the human head and a wireless device is one of them. The specific absorption rate is defined with the power absorbed per mass of biological tissue and it is expressed with the units of watts per kilogram (W/kg). Currently, two international bodies have developed guidelines for limiting the effects of the electromagnetic radiation on human health. The EM absorption limit specified in IEEE C95.1:2005 ${ }^{6}$ is 1.6 $\mathrm{W} / \mathrm{kg}$ in a $1 \mathrm{~g}$ averaging mass and $2 \mathrm{~W} / \mathrm{kg}$ in a $10 \mathrm{~g}$ averaging mass of tissue, which is similar to the limit stated in the International Commission on Non-Ionizing Radiation Protection (ICNIRP) guideline.

Table 4: SAR values of the proposed antenna

Tabela 4: Vrednosti SAR za predlagano anteno

\begin{tabular}{|c|c|c|c|c|}
\hline $\begin{array}{c}\text { Frequency } \\
(\mathrm{GHz})\end{array}$ & $\begin{array}{c}\text { SAR for 1 g } \\
(\mathrm{W} / \mathrm{kg})\end{array}$ & $\begin{array}{c}\text { SAR for } \\
10 \mathrm{~g}(\mathrm{~W} / \mathrm{kg})\end{array}$ & $\begin{array}{c}\text { Absorbed } \\
\text { power } \\
(\mathrm{rms}) \mathrm{W}\end{array}$ & $\begin{array}{c}\mathrm{S}_{11} \text { with } \\
\text { human head } \\
\text { model }(\mathrm{dB})\end{array}$ \\
\hline 1.8 & 1.10 & 0.763 & 0.1179 & -10.5 \\
\hline 2.4 & 1.04 & 0.715 & 0.0957 & -12.76 \\
\hline
\end{tabular}

In designing antennas for wireless communication, it is very important to analyze the SAR values of the proposed antenna. In this research, a SAR analysis was performed, with the reference power of the wireless device set to $500 \mathrm{~mW}$. The distance between the head and the handset was $4.5 \mathrm{~mm}$. Moreover, the commercially available CST Microwave Studio software head-phantom model was adopted for this study. The head phantom is

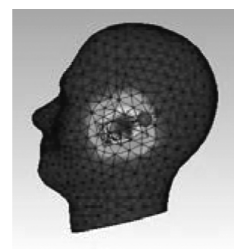

(a)

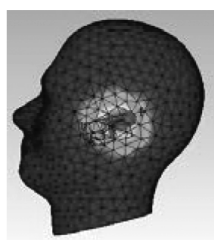

(c)

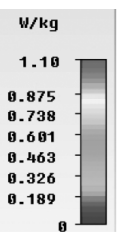

-

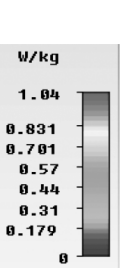

.

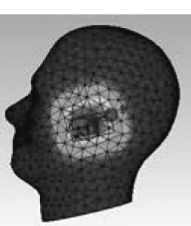

(b)

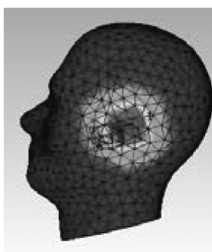

(d)

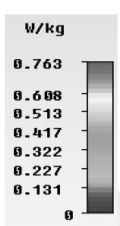

${ }_{2}$

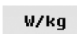

Figure 8: a) $1 \mathrm{~g} \mathrm{SAR}$ at $1.8 \mathrm{GHz}$, b) $10 \mathrm{~g} \mathrm{SAR}$ at $1.8 \mathrm{GHz}$, c) $1 \mathrm{~g} \mathrm{SAR}$ at $2.4 \mathrm{GHz}$ and d) $10 \mathrm{~g} \mathrm{SAR}$ at $2.4 \mathrm{GHz}$

Slika 8: a) $1 \mathrm{~g}$ SAR pri $1,8 \mathrm{GHz}$, b) $10 \mathrm{~g}$ SAR pri $1,8 \mathrm{GHz}$, c) $1 \mathrm{~g}$ SAR pri $2,4 \mathrm{GHz}$ in d) $10 \mathrm{~g} \mathrm{SAR}$ pri $2,4 \mathrm{GHz}$

made of two layers, one is the shell and the other is fluid. The shell material specifications are: $\varepsilon=5, \mu=1, \tan \delta=$ 0.05 ; and the specifications of the fluid inside the shell are: $\varepsilon=42, \mu=1$, el. conductivity of $0.99 \mathrm{~S} / \mathrm{m}$, fluid density of $1000 \mathrm{~kg} / \mathrm{m}^{3}$. In addition, the SAR values at 1.8 $\mathrm{GHz}$ and $2.4 \mathrm{GHz}$ are presented in Figure 8 and listed in Table 4. The obtained $1 \mathrm{~g}$ SAR for the proposed antenna at $1.8 \mathrm{GHz}$ is $1.10 \mathrm{~W} / \mathrm{kg}$, which is about $27 \%$ less than the reference value. ${ }^{3}$

\section{CONCLUSION}

This paper presents a new printed planar antenna for GPS, GSM, WLAN, LTE band 40, WiMAX and WLAN wireless applications with a better antenna performance, including impedance bandwidth, antenna gain, radiation pattern and radiation efficiency obtained over operating bands. The experimental results validated the simulated ones. Moreover, the proposed antenna satisfies the requirements relating to the specific absorption rate. Therefore, the overall performance of the proposed antenna makes it suitable for the wireless mobile application.

\section{REFERENCES}

${ }^{1}$ W. C. Liu, C. M. Wu, Y. Dai, Design of triple-frequency microstrip-fed monopole antenna using defected ground structure, IEEE Transactions on Antennas and Propagation, 59 (2011), 2457-2463, doi:10.1109/TAP.2011.2152315

${ }^{2}$ T. Alam, M. R. I. Faruque, M. T. Islam, Printed Circular Patch Wideband Antenna for Wireless Communication, Informacije MIDEM, 44 (2014), 212-217

${ }^{3}$ D. Zhou, R. A. Abd-Alhameed, C. H. See, A. G. Alhaddad, P. S. Excell, Compact wideband balanced antenna for mobile handsets, IET Microwaves, Antennas \& Propagation, 4 (2010), 600-608, doi:10.1049/iet-map.2009.0153

${ }^{4}$ Q. Rao, T. A. Denidni, New broadband dual-printed inverted L-shaped monopole antenna for tri-band wireless applications, Microwave and optical technology letters, 49 (2007), 278-280, doi:10.1002/mop. 22107 
${ }^{5}$ S. B. Chen, Y. C. Jiao, W. Wang, F. S. Zhang, Modified T-shaped planar monopole antennas for multiband operation, IEEE Transactions on Microwave Theory and Techniques, 54 (2006), 3267-3270, doi:10.1109/TMTT.2006.877811

${ }^{6}$ IEEE Standard for Safety Levels with Respect to Human Exposure to Radio Frequency Electromagnetic Fields, $3 \mathrm{kHz}$ to $300 \mathrm{GHz}$, IEEE Std C95.1-2005 (Revision of IEEE Std C95.1-1991), 2006, pp. 0_1-238, doi:10.1109/IEEESTD.2006.99501

${ }^{7}$ International Non-Ionizing Radiation Committee of the International Radiation Protection Association, Guidelines on limits on exposure to radio frequency electromagnetic fields in the frequency range from $100 \mathrm{kHz}$ to $300 \mathrm{GHz}$, Health Physics, 54 (1988), 9

${ }^{8}$ I. Yarovsky, E. Evans, Computer simulation of structure and properties of crosslinked polymers: application to epoxy resins, Polymer, 43 (2002), 963-969, doi:10.1016/S0032-3861(01)00634-6
${ }^{9}$ M. Samsuzzaman, M. Islam, J. Mandeep, N. Misran, Printed wideslot antenna design with bandwidth and gain enhancement on low-cost substrate, The Scientific World Journal, 2014 (2014), article ID 804068, doi:10.1155/2014/804068

${ }^{10}$ M. R. I. Faruque, M. T. Islam, N. Misran, Evaluation of specific absorption rate (SAR) reduction for PIFA antenna using metamaterials, Frequenz, 64 (2010), 144-149, doi:10.1515/FREQ.2010.64.7-8.144

${ }^{11}$ M. R. I. Faruque, M. T. Islam, N. Misran, Influence of SAR Reduction in Muscle Cube with Metamaterial Attachment, Informacije Midem-Journal of Microelectronics, Electronic Components and Materials, 41 (2011), 233-237

${ }^{12}$ M. R. I. Faruque, M. T. Islam, Novel Triangular Metamaterial Design for Electromagnetic Absorption Reduction in Human Head, Progress in Electromagnetics Research, 141 (2013), 463-478, doi:10.2528/ PIER13050603 